UDC 53.082:612.017.1

\title{
CORRELATIVE PROCESSING OF INFORMATION IN BIOSENSORS BY SURFACE PLASMON RESONANCE
}

\author{
I. Voitovych, I. Yavorsky \\ V.Glushkov Institute of Cybernetics of the National Academy of Sciences of Ukraine, 40, Academician \\ Glushkov av., 03680, Kyiv, Ukraine. Telephone:38-044 5260128, Facsimile: 38-044 5263348, \\ e-mail: d220@public.icyb.kiev.ua

\section{CORRELATIVE PROCESSING OF INFORMATION IN BIOSENSORS BY SURFACE PLASMON RESONANCE}

\begin{abstract}
I. Voitovych, I. Yavorsky
Abstract. The paper considers the possibility of using the anti-noise correlation technique of signal processing in biosensors based on surface plasmon resonance (SPR sensors). Application of the said technique is rationalized to define the coordinate shift of resonance parameter which indicates analyte available in the sample under investigation. The example of analytic calculation of correlation signal is presented for Gauss distribution of information luminous flux intensity. It is shown that the correlation technique being dependant on the specific purpose and the cost of a sensor can provide angular resolution $\Delta \theta_{\min } \sim 0,01^{0}-0,0003^{\circ}$.
\end{abstract}

Keywords: surface plasmon resonance, SPR sensor, correlation technique, resolution capacity

\section{КОРЕЛЯЦЙНА ОБРОБКА ІНФОРМАЦІЇ В БІОСЕНСОРАХ НА ОСНОВІ ПОВЕРХНЕВОГО ПЛАЗМОННОГО РЕЗОНАНСУ}

\section{І. Д. Войтович, І. О. Яворський}

Анотація. Розглянута можливість використання антишумового кореляційного методу обробки сигналів в біосенсорах на основі поверхневого плазмонного резонансу (ППР-сенсорах). Обгрунтоване застосування вказаного методу для визначення координатного зсуву резонансної характеристики, який є показником наявності аналіту в досліджуваній пробі. Наведено приклад аналітичного розрахунку кореляційного сигналу для гаусівського розподілу інтенсивності інформаційного світлового потоку. Показано, що кореляційний метод, в залежності від конкретного призначення і вартості сенсора, може забезпечити кутову роздільну здатність $\Delta \theta_{\min } \sim 0,01^{0}-0,0003^{\circ}$.

Ключові слова: поверхневий плазмонний резонанс, ППР-сенсор, кореляційний метод, роздільна здатність 


\title{
КОРЕЛЛЯЦИОННАЯ ОБРАБОТКА ИНФОРМАЦИИ В БИОСЕНСОРАХ НА ОСНОВЕ ПОВЕРХНОСТНОГО ПЛАЗМОННОГО РЕЗОНАНСА
}

\section{И. Д. Войтович, И. А. Яворский}

\begin{abstract}
Аннотация. Рассмотрена возможность использования антишумового корелляционного метода обработки сигналов в биосенсорах на основе поверхностного плазмонного резонанса (ППР-сенсорах). Обосновано применение указанного метода для определения координатного сдвига резонансной характеристики, являющегося показателем присутствия аналита в исследуемой пробе. Приведен пример аналитического расчёта корелляционного сигнала для гауссовского распределения интенсивности информационного светового потока. Показано, что корелляционный метод, в зависимости от конкретного назначения и стоимоти сенсора, может обеспечить угловое разрешение $\Delta \theta_{\min } \sim 0,01^{0}-0,0003^{0}$.
\end{abstract}

Ключевые слова: поверхностный плазмонный резонанс, ППР-сенсор, корелляционный метод, разрешающая способость

\section{Introduction}

For the SPR sensor to be operated efficiently, it is essential to determine correctly the coordinates of the angular distribution intensity of the luminous flux reflected from the sensitive receiver chip. The resonance curve of the sensor corresponding to the above distribution is usually noise-affected and has no designated minimum. Therefore, it is rather difficult to define with sufficient precision its shift from a reference curve which characterizes the examined sample in quantitative terms, e.g. indicating the analyte available.

Parasitic optical reflections in an optoelectronic channel and that of receiving chip are the sources of the SPR sensor noise. In addition, the SPR sensors are affected by the factors related to the ultimate dimensions of the radiation source and photosensitive elements, production flaws and adjustment precision of the optical elements, monochromic radiation etc. This results in the limitation of physical angular separate capacity of the sensor (if there is no or insufficient designated program algorithmic processing of the information signals) by the values of several tenth of a degree [1]. For instance, in the sensor described in [2], the precision of $\sim 0,01^{\circ}$ of the turning angle of a prism makes an angular separate capacity $\Delta \theta_{\min } \sim 0,3^{\circ}$. Sensor Spreeta by Texas Instruments, on the other hand, employing the luminodiode with the emitting area of $\sim 200 \mathrm{mcm}$, wave length $\lambda \sim 830 \mathrm{~nm}$ and monochromaticity $\Delta \lambda \sim 15 \mathrm{~nm}$ and discreet photo detecting line of 128 pixels with basic distance between the radiation source and photodetector $\sim 5-7 \mathrm{~cm}$ the physical angular separate capacity makes mere $\Delta \theta_{\min } \sim 2,3^{0}[1,3]$. All this can be explained by an ambiguity (fault) of the angular position of a resonance parameter as resulting from the instability factors described above in action.

Traditional approaches (design improvements, installation of diaphragms, coating of the optics, application of various absorbing coatings as well as band pass electric filters on the signal's way etc.) unfortunately allow only partial decrease of noises and interferences. The only radical solution in our view is to employ electronic devices of filtration and processing of information signals $[1,4]$. For this purpose it is feasible to apply correlation technique in the SPR sensor [5]. It uses integral properties of a data array defining the whole resonance parameter of the sensor.

\section{Phenomena model}

Let us consider the SPR sensor, in which the angular scanning of light on a receiving chip is made by means of a luminous flux with an angular distinction. Let the intensity distribution of a reflected luminous flux (resonance parameter) on the surface of a photo detector (photosensitive CCD range) corresponding to the clean (analyte-free) sample under examination looks as follows:

$$
F(x)=I(x-\delta)+S(x),
$$

where $I(x-\delta)-$ an information component of the distribution, $x$ - coordinate along the CCD range, $\delta-$ ambiguity (fault) of the information component position due to instability factors ( $\delta$ can be preceded with different signs), $S(x)-$ noise component. Expression (1) will designate a etalon signal. 
Light intensity distribution which corresponds to the sample with analyte also contains information and noise components and looks as follows:

$$
\tilde{F}(x)=\tilde{I}(x-\delta)+\tilde{S}(x) .
$$

Expression (2) will define the operating signal.

It is worth mentioning that functions (1) and (2) are not identical as the resonance parameters for the clean samples and the sample with an analyte can be shifted against each other by the $\mathrm{x}$ axis by the value $\xi$ which is an amount of analyte available in the sample. Such functions are defined in the range $-\frac{L}{2} \leq x \leq+\frac{L}{2}$, where $L-$ value of photosensitive area of the CCD range on which resonance parameters are registered. Such amount is defined by the expected range of the shifts of the resonance angles of the SPR $\theta_{0}$ and e.g. with $\theta_{0}=64,5 \pm 3^{0}$ it makes $\sim 1 \mathrm{~cm}$. General look of the functions $F(x), \tilde{F}(x), I(x-\delta), \tilde{I}(x-\delta)$, which provides their qualitative characteristic is shown on fig. 1.

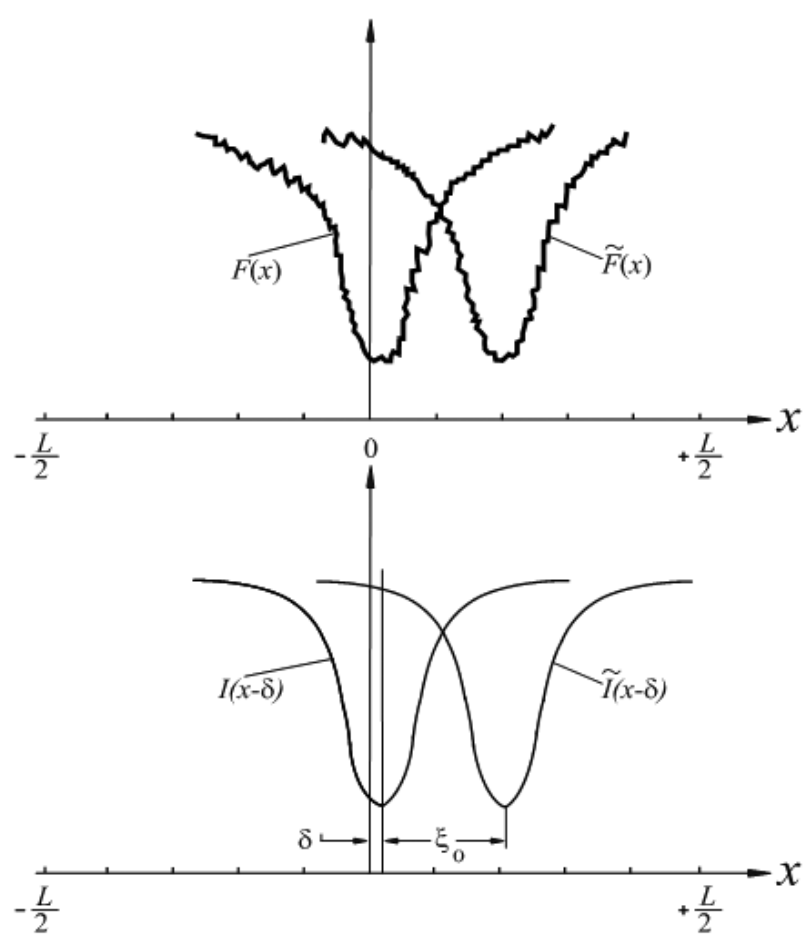

Fig. 1. The overall qualitative appearance of the function of the reflected light intensity distribution for the net sample $F(x)$ and the sample with analyte $\tilde{F}(x)$ along with their data components $I(x-\delta)$ i $\tilde{I}(x-\delta)$.

The correlation technique is to ensure finding of the value of the coordinate shift $\xi=\xi_{0}$, which occurs between the reference and operation signals with the analyte available in a sample under inves- tigation. To this end firstly for the reference signal $F(x)$ we develop its autocorrelation function $\psi(\xi)$ as follows:

$$
\begin{gathered}
\psi(\xi)=\int_{-\frac{L}{2}+\xi}^{+\frac{L}{2}} F(x) F(x-\xi) d x= \\
=\int_{-\frac{L}{2}+\xi}^{+\frac{L}{2}} I(x-\delta) I(x-\delta-\xi) d x+ \\
+\int_{-\frac{L}{2}+\xi}^{+\frac{L}{2}} I(x-\delta-\xi) S(x) d x+ \\
+\int_{-\frac{L}{2}+\xi}^{+\frac{L}{2}} I(x-\delta) S(x-\xi) d x+\int_{-\frac{L}{2}+\xi}^{+\frac{L}{2}} S(x) S(x-\xi) d x .
\end{gathered}
$$

For the $1^{\text {st }}$ integral in (3) having replaced the variable the following can be constructed:

$$
\begin{gathered}
\int_{-\frac{L}{2}+\xi}^{+\frac{L}{2}} I(x-\delta) I(x-\delta-\xi) d x= \\
=\int_{-\frac{L}{2}+\xi-\delta}^{+\frac{L}{2}-\delta} I(z) I(z-\xi) d z=\int_{-\frac{L}{2}+\xi}^{+\frac{L}{2}} I(z) I(z-\xi) d z+ \\
+(\Delta \psi)_{\delta}
\end{gathered}
$$

where

$$
\begin{aligned}
& (\Delta \psi)_{\delta}=\delta \cdot\left[I\left(-\frac{L}{2}+\xi-\frac{\delta}{2}\right) \cdot I\left(-\frac{L}{2}-\frac{\delta}{2}\right)-\right. \\
& \left.-I\left(\frac{L}{2}-\xi-\frac{\delta}{2}\right) \cdot I\left(\frac{L}{2}-\frac{\delta}{2}\right)\right]
\end{aligned}
$$
of the $\delta$ effect can be done provided

$$
\begin{gathered}
\int_{-\frac{L}{2}+\xi}^{+\frac{L}{2}} I(x-\delta) I(x-\delta-\xi) d x \approx \\
\approx \int_{-\frac{L}{2}+\xi}^{+\frac{L}{2}} I(z) I(z-\xi) d z=\int_{-\frac{L}{2}+\xi}^{+\frac{L}{2}} I(x) I(x-\xi) d x,
\end{gathered}
$$


when $(\Delta \psi)_{\delta} \approx 0$. This requires in its turn $I\left(-\frac{L}{2}\right)=I\left(\frac{L}{2}\right)$, i.e. on the limits of integration the information component is to have similar values. It results in that the value of the said integral (from mathematical standpoint the area limited with subintegral function and $\mathrm{x}$-axis) will not depend on the shift of the information component along the axis and the impact of the coordinate ambiguity $\delta$ will be gone.

Three last integrals in expression (3) with the precision up to the value of the $2^{\text {nd }}$ infinitesimal order $(\Delta \psi)$, equal to " 0 ", as wideband statistical noises $S(x)$ i $S(x-\xi)$ do not correlate with the functions $I(x-\delta)$ i $I(x-\delta-\xi)$ and between each other. This conclusion is true for the integration of functions oscillating rapidly (noises correlate with the similar oscillations) [6].

Filtration properties of the correlation technique but ensure removal of the instabilities and noises. After the filtration expression (3) with the precision up to $\Delta \psi_{\Sigma}=(\Delta \psi)_{\delta}+(\Delta \psi)_{s} \approx 0$ will look as follows:

$$
\psi(\xi)=\int_{-\frac{L}{2}+\xi}^{+\frac{L}{2}} I(x) I(x-\xi) d x \pm \Delta \psi_{\Sigma} .
$$

Theoretically, while the correlation technique is applied the effect of the coordination shift and noises can be reduced to zero so as the annex connected therewith $\Delta \psi_{\Sigma}=0$. However separate capacity will be then defined not by the destabilization factors depicted above but by the threshold of the response of a registering device and digit capacity of its $\mathrm{AD}$ converter.

Next step is to calculate the specific value $\psi\left(\xi_{0}\right)$ of the mutual correlation function for $F(x)$ and $\tilde{F}(x)$ :

$$
\psi\left(\xi_{0}\right)=\int_{-\frac{L}{2}}^{+\frac{L}{2}} F(x) \tilde{F}(x) d x .
$$

Accounting for the mentioned above filtration, one has:

$$
\psi\left(\xi_{0}\right) \approx \int_{-\frac{L}{2}}^{+\frac{L}{2}} I(x) \tilde{I}(x) d x .
$$

It is clear, that in practice it is necessary to apply numeric techniques of finding autocorrelation and mutual correlation functions as the distributions $F(x)$ and $\tilde{F}(x)$ are assigned experimentally.
For numeric calculations the popular rule applies, that is, for instance, the integral value in (7) can be obtained by adding the discrete values of coupled products of signals $F(x) \cdot \tilde{F}(x)$, multiplied by intervals $\Delta x$, such as

$$
\psi\left(\xi_{0}\right)=\sum_{j=0}^{N} F\left(-\frac{L}{2}+j \Delta x\right) \cdot \tilde{F}\left(-\frac{L}{2}+j \Delta x\right) \cdot \Delta x .
$$

To provide the higher precision level of the calculations, the interval lengths $\Delta x$ are not to be extended $\left(\Delta x \sim 10 \cdot 10^{-4} \mathrm{~cm}\right)$, and number $N=\frac{L}{\Delta x}$ is to be substantial $(N \sim 1000)$. The total calculation duration for the correlation function inside the microcomputer (inclusive of the time needed for converting signals into the digital format) is $\leq 1 s$, which is an acceptable value.

Fig. 2 presents the configuration of the device intended for processing of SPR signals with the correlation method. This configuration differs from the layouts traditionally employed for similar purposes only by its software algorithm [7].

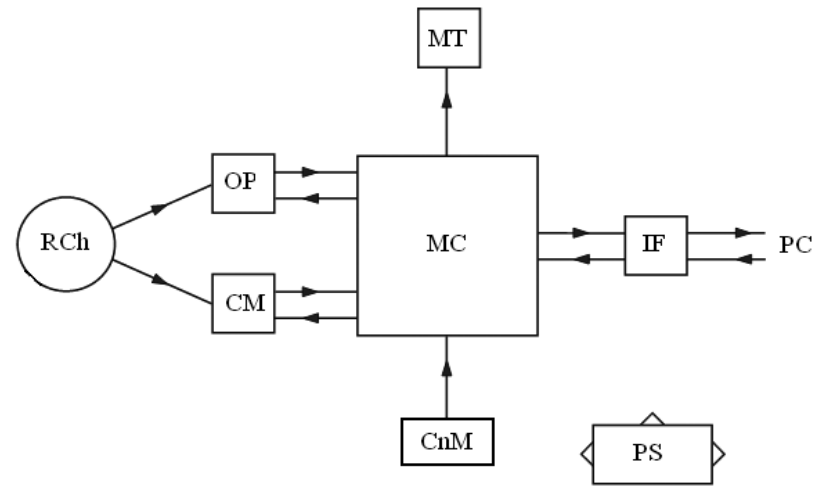

FIg. 2. The configuration scheme of the device for the correlation data processing: $\mathrm{RCh}$ - receiver chip, OPoptical receiver, $\mathrm{MC}-$ microcomputer, $\mathrm{MT}$ - monitor, $\mathrm{CnM}$ - control module, CM - communication module, IF - interface, PS - power supply module.

At first, the optical receiver $O P$ registers and stores, inside the microcomputer $M C$, the light intensity distribution value $F(x)$ obtained from the "etalon" sample located at the receiver chip $R C h$. Next, the corresponding 'etalon' auto-correlation function $\psi(\xi)$ is being calculated (including the numerical integration) and is stored inside $M C$. After that, the light intensity distribution from the analyte $\tilde{F}(x)$ is registered and stored (this distribution comprises the data on shift $\xi_{0}$ ). Further on, $F(x)$ and $\tilde{F}(x)$ are used to calculate in the $M C$ the concrete value of the inter-correlation function $\psi\left(\xi_{0}\right)$, which is also being registered. Given 
the latter value, with the "etalon" correlation $\psi(\xi)$ stored inside the $M C$, the corresponding value $\xi_{0}$ is obtained. The outcomes are shown at the monitor $M T$ and could be transmitted further, via the interface $I F$, on to the external personal computer $P C$ for further data processing and accumulation. The change in the conditions of the analysis (the change of an individual under examination, relocation and replacements of receiver chips, etc.) is performed via communication module $C n M$. The control of the device is performed by control module $C M$, and power supply is provided by module $P S$.

Below is the analytical calculation of an autocorrelation function $\psi(\xi)$ for an instance approximated to the real conditions (Fig.1), when

$$
\begin{gathered}
I(x-\delta)=I_{0}\left(1-e^{-\alpha(x-\delta)^{2}}\right)+\text { const }, \\
S(x)=\sum_{i=1}^{n} a_{i} \sin \left(\omega_{i} x+\phi_{i}\right),
\end{gathered}
$$

where $a_{i}, \omega_{i}, \phi_{i}$ is the amplitude, circular frequency and the phase of the corresponding noise components (such as sinusoidal). Number $n$ of the such components can be rather extended, as the noise is multi-band. Primarily, for the reasons of convenience, the expression for $I(x-\delta)$ is to be simplified by taking out the constant component $I_{0}+$ const, hence, the intensity distribution of the reflected light becomes similar to the gauss format:

$$
I(x-\delta)=-I_{0} e^{-\alpha(x-\delta)^{2}} .
$$
is true:

Then, for the first integral in (3) the following

$$
\begin{gathered}
J_{1}=\int_{-\frac{L}{2}+\xi}^{+\frac{L}{2}} I(x-\delta) I(x-\delta-\xi) d x= \\
=I_{0}^{2} e^{-\frac{\alpha}{2} \xi^{2}} \int_{-\frac{L}{2}+\xi}^{+\frac{L}{2}} e^{-\frac{\alpha}{2}(2 x-2 \delta-\xi)^{2}} d x .
\end{gathered}
$$

The second integral in (3) becomes

$$
J_{2}=\sum_{i=1}^{n} \int_{-\frac{L}{2}+\xi}^{+\frac{L}{2}} I(x-\xi) \cdot a_{i} \sin \left(\omega_{i} x+\phi_{i}\right) d x .
$$

Next, in compliance with integration rules for accelerated oscillating functions [6]

$$
J_{2} \approx \sum_{i=1}^{n} \frac{I_{0} a_{i}}{\omega_{i}}\left\{e^{-\alpha\left(\frac{L}{2}-\xi\right)^{2}} \cos \left(\omega_{i} \frac{L}{2}+\phi_{i}\right)-\right.
$$

$$
\left.-e^{-\alpha\left(\frac{L}{2}\right)^{2}} \cos \left[\omega_{i}\left(-\frac{L}{2}+\xi\right)+\phi_{i}\right]\right\} .
$$

It is obvious that with the high values of the circular frequencies $\omega_{i}$, integral $J_{2} \approx 0$, i.e. the noise is being filtered. The $3^{\text {rd }}$ integral in (3) is approximated to 0 in the similar manner.

The next step is to show that the $4^{\text {th }}$ interval in (3) is also close to 0 . The expression for this is:

$$
\begin{gathered}
J_{4}=\int_{-\frac{L}{2}+\xi}^{+\frac{L}{2}} \sum_{i=1}^{n} a_{i} \sin \left(\omega_{i} x+\phi_{i}\right) \times \\
\times \sum_{i=1}^{n} a_{i} \sin \left[\omega_{i}(x-\xi)+\phi_{i}\right] d x .
\end{gathered}
$$

The sub-integral total values in (15) can be replaced with their mean values:

$J_{4} \approx n^{2} \bar{a}^{2} \overline{\sin (\omega x+\phi)} \cdot \overline{\sin [\omega(x-\xi)+\phi]} \cdot(L-\xi)$.

As $\overline{\sin (\omega x+\phi)}=0$, then $J_{4} \approx 0$.

As was intended by substantiation (4) - (5), integration (12) leads to eliminating of the impact from coordination shift $\delta$, as irrelevant to the latter shift, the sub-integral exponent at the integration margins is characterized by practically identical values. As the result, autocorrelation function $\psi(\xi) \approx J_{1}$, and corresponding standardized function $\bar{\psi}(\xi)$ becomes:

$$
\bar{\psi}(\xi)=\frac{\psi(\xi)}{I_{0}^{2}} \approx \sqrt{\frac{\pi}{2 \alpha}} e^{-\frac{\alpha}{2} \xi^{2}} \Phi(t),
$$

where $\Phi(t)$ is credibility integral, $t=\sqrt{\alpha}(L-\xi)$ [6].

To determine $\xi_{0}$, the value of inter-correlative function $\psi\left(\xi_{0}\right)$ (such as from (8)) is to be introduced in equation (17), which is next resolved relative to $\xi$. This can be done with numerical methods only, as $\xi$ is not a direct component of (17). An essentially similar operation is performed inside our microcomputer $M C$ by means of comparing the values of auto-correlation and inter-correlation functions.

Fig. 3 shows standardized gauss light intensity distribution $\bar{I}(x)$ and corresponding auto-correlation function $\bar{\psi}(\xi)$, both calculated analytically. As the value of the correlation function is related to shift $\xi$ between the signals generating it, this enables to determine the above shift in each particular instance. For instance, with the change of correlation function $\Delta \bar{\psi}_{\text {min }}=0,001 \cdot \bar{\psi}_{\text {max }} \approx 1,5 \cdot 10^{-4} \mathrm{~cm}$, that can equal the total value of the inconsistency 
and noise $\Delta \bar{\psi}_{\Sigma}$, the minimum shift (linear distributive capacity) is $\xi_{\min } \approx 35 \cdot 10^{-4} \mathrm{~cm}$. In an inexpensive portable SPR sensor, with the standard distance between the radiation source point and the optical receiver line of $\sim 10-15 \mathrm{~cm}$, this would correspond to angular distributive capacity $\Delta \theta_{\min } \sim 0,01^{0}$.
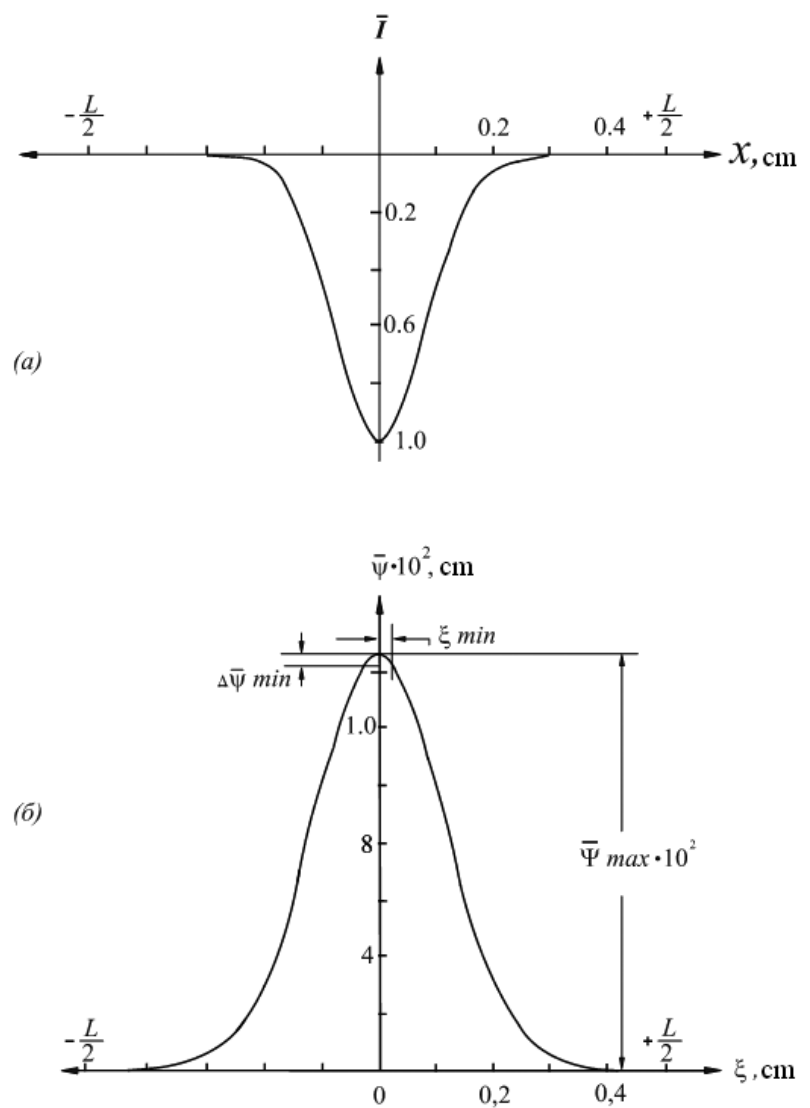

Fig. 3. Standardized gauss distribution of the reflected light intensity distribution $\bar{I}(x)=-e^{-75 x^{2}}$ (a) and its $a u$ tocorrelation function $\bar{\psi}(\xi)$ (б).

Linear distributive capacity $\xi_{\min }$ (the corresponding angular distributive capacity is $\Delta \theta_{\text {min }}$ ) is an important parameter in the correlation method. As was observed earlier, ideally, in case of complete elimination of the impact from the inconsistencies and the noise, it is determined by the minimum shift in the correlation signal $\Delta \bar{\psi}_{\text {min }}$, that can be whatsoever registered. For the suggested instance of a gauss distribution the linear distributive capacity is described with the expression:

$$
\xi_{\min }=\frac{\left|\Delta \bar{\psi}_{\min }\right|}{\left|\frac{\partial \bar{\psi}}{\partial \xi}\right|_{\xi=\xi_{\min }}} \approx\left[\frac{2}{\pi \alpha}\left(\Delta \bar{\psi}_{\min }\right)^{2}\right]^{1 / 4} .
$$

It is clear that the distributive capacity can be increased $\left(\xi_{\min }\right.$ can be decreased) by increasing the sensitivity of registering devices (by decreasing $\Delta \bar{\psi}_{\text {min }}$ ) and by increasing the ratio of the correlation function $\left|\frac{\partial \bar{\psi}}{\partial \xi}\right|_{\xi=\xi_{\min }}$. For the same gauss distribution with $\Delta \bar{\psi}_{\min }=1 \cdot 10^{-6} \bar{\psi}_{\max }=1,5 \cdot 10^{-7} \mathrm{~cm}$ one can obtain $\xi_{\min }=1 \cdot 10^{-4} \mathrm{~cm}$ and correspondingly $\Delta \theta_{\min }=0,0003^{\circ}$. For this, the sensor should have an ADC with the order level of $N=20$ (it is determined with the expression $\frac{\bar{\psi}_{\max }}{\Delta \bar{\psi}_{\min }}=2^{N}$ ).

In existing sensors, depending on their configuration, application and cost, the distributive capacity can vary within a wide range - from several 0.1 [2] up to several $10^{-4}$ degrees [8]. Increase in distributive capacity is typically achieved by multiple measurements of data signals (in order to average the results and increase the "signal-noise" ratio), by selecting adequate registering devices and software applications, and also by performance configuration of the optic electronic channel. In this connection, findings [9] of achieving angular distributive capacity $\Delta \theta_{\min } \sim 0,0001^{0} \quad(0,1$ millideg ree $)$ is of particular interest, although no particular methods, their complexity or cost are being specified.

The achieved range of the angular distributive capacity $\Delta \theta_{\min } \sim 0,01^{0}-0,0003^{0}$ is the evidence of the vast application potential of the correlation method. For instance, value $\Delta \theta_{\min } \sim 0,01^{0}$ is applicable for inexpensive portable SPR sensors intended to operate in field conditions. In SPR refractometers this value corresponds to the difference of the examined substance refraction parameter $\Delta n \sim 0,1 \cdot 10^{-5}$ [10], which is higher than the relative values of the renowned sensor BIACORE 2000 (its sensitivity is $\left.\Delta n \sim 1 \cdot 10^{-5}\right)$. The similar order of the calculation value (not physical property) of the calculated distributive capacity $\left(\sim 0,03^{0}\right)$ is achieved in the mentioned above sensor Spreeta [3], yet this sensor is rather a lab device and the data are processes with the external computer and complex software application. As for the value $\Delta \theta_{\text {min }} \sim 0,0003^{0}$, there is a particular need in SPR sensors characterized by such distributive capacity, as, to achieve this, the existing limitations are to be surpassed in terms of specifications for registering and processing of the data (sensitivity, numerical order ADC, etc.) and the incurred costs. Increased distributive capacity also demands optimization of formatting methods, in particular, registration and processing procedures for the sensor data signals, as well as introduction of 
the complementary methods, such as optical phasometry techniques, etc. $[9,11]$.

It is worth mentioning, that though eliminating the impact from coordinate ambiguity $\delta$ noise filtering are important properties of the correlation method, these are not its only advantages. Both the "etalon" and the "operational" signals of the SPR sensor can have insignificant minimum values. Hence, if identifying the shift $\xi_{0}$ between these signals with direct methods (such as with the signal minimums), it is difficult to select a reference point. Even in case of complete noise elimination it would be difficult to achieve the needed precision of the measurements. As was mentioned above, the correlation method employs the vast data base to determine the shift value (thousands of gauge results from the signal, including registries from its side beams). For instance, according to (9) each value of the inter-correlation function $\psi\left(\xi_{0}\right)$ accumulates inside it the data from $2 N \sim 2000$ values of the "etalon" and "operational" signals. That is why applying the correlation method means high levels of the data averaging and hence high precision of measurements, there is no longer need to determine the measurement reference points.

There is also a possibility of instances when the "etalon" and the "operational" signals are shifted between themselves to the extent that they are not overlaid at any point. Then the relevant value of the inter-correlation function equals 0 . This in turn means that the correlation method cannot determine shift $\xi_{0}$. Yet, in this particular case, there is no need to apply the former method and one can refer to the above-mentioned simpler approaches. For this, the software can be furnished, for example, by sub-programs to determine the shift with the points of changing the polarity of the derivatives at signal minimums or by the method of "moments" [3].

\section{Conclusions}

1. It was shown that with the help of the correlation method in SPR sensors there can be eliminated the coordinate ambiguity of the resonance parameter related to the finite dimensions of the light source, optically sensitive elements, faults in the configuration, the precision limits of adjustment and the monochromatic property of the radiation, as well as the noise, also there could be achieved the angular distributive capacity $\Delta \theta_{\min } \sim 0,01^{0}-0,0003^{\circ}$.
2. The further increase of the distributive capacity is related to the updating of the existing formatting methods, methods of registering and processing of the information signals and their back-up with alternative approaches.

\section{References}

1. Боюн В. П., Войтович І. Д. та ін. Сенсорний пристрій // Пат. України №78998. МПК G01 N21/55. Заявл. 27. 12. 2004, опубл. 10. 05. 2007. - Бюл. №6.

2. Ширшов Ю. М., Венгер Є. Ф. та ін. Спосіб детектування та визначення концентрації біомолекул та молекулярних комплексів та пристрій для його здійснення // Пат. України №46018. МПК G01 N21/55. Заявл. 22. 10. 1997, опубл. 15.05.2002. - Бюл №5.

3. Suzuki M., Ozawa F., Sugimoto W., Aso S. Miniaturization of SPR Immunosensors // Analytical Sciences. - 2001. - V. 17. - P. 1265-1267; www. ti. $\mathrm{com} / \mathrm{spreeta}$; www. aigproducts. com/surface plasmon resonance/spr curve analusis. htm.

4. Войтович И. Д., Корсунский В. М., Косогор А. Н., Стародуб Н. Ф., Яворский И. А. Перспективы создания портативных биосенсоров на основе поверхностного плазмонного резонанса // Сенсорная электроника и микросистемные технологии. -2005 . - №. 3. - С. $56-65$.

5. Голдман С. Теория информации. - М.:И. Л., 1957. - C. $325-331$.

6. Зельдович Я. Б., Мышкис А. Д. Элементы прикладной математики. - М.:Наука, 1972. С. $79-82,510$.

7. Войтович І. Д., Корсунський В. М. Інтелектуальні сенсори. - Київ: ІК НАНУ, 2007. - С. 5-67.

8. Ширшов Ю. М., Самойлов А. В. и др. Анализ и численное моделирование ППР-спектрометров с механической развёрткой по углу: алгоритм определения угловой позиции минимума // Реєстрація, зберігання і обробка даних. - 2004. T. 6. - №3. - C. 3-18.

9. Handbook of Surface Plasmon Resonance (Edit. by R. B. M. Schasfoort and Anna J. Tudos, Netherlands). -2008 . - P. $22-23,59$.

10. Stemmler I., Brecht A., Gauglitz G. Compact surface plasmon resonance-transducers with spectral readout for biosensing applications // Sensors and Actuators. - B. 54. - 1999. - P. 98 - 105.

11. Кабашин А. В., Никитин П. И. Интерферометр с использованием поверхностного плазмонного резонанса для сенсорных измерений // Квантовая электроника. - 1997. - Т. 24. - №7. C. $671-672$. 